\title{
35- Ĕ̆itim teknolojilerinin otizmde kullanımına dil ve konuşma terapistleri nasıl bakıyor?
}

\section{Sibel ERGÜN ELVERICI'1 \\ OkTay TAYMAZ SARI²}

\begin{abstract}
APA: Ergün Elverici, S.; Taymaz Sarı, O. (2021). Eğitim teknolojilerinin otizmde kullanımına dil ve konuşma terapistleri nasıl bakıyor? RumeliDE Dil ve Edebiyat Araştırmaları Dergisi, (25), 564-578. DOI: $10.29000 /$ rumelide.1032442.
\end{abstract}

$\ddot{O} \mathbf{z}$

Sosyal etkileşim, iletişim ve davranış sorunlarıyla kendini gösteren otizm, bireylerin hayatını büyük ölçüde etkilemektedir. Özellikle dil gelişiminde gecikme ya da hiç konuşamama, başka bireylerle sohbet başlatma, sürdürme ya da sonlandırma konusunda yaşanan güçlükler sık yaşanan sorunların başında gelmektedir. Göz teması kurmaktan kaçınmak, akran oyunlarına katılmamak, başkalarıyla etkileşim kurmaktan kaçınmak, etkileşim gerektiren oyunlarda yaşanan güçlükler ve yinelenen konuşma (ekolali) diğer iletişimsel problemler arasında yer almaktadır. Otizm tanısı almış çocukların eğitimine yönelik uygulanan birçok yaklaşımdan bahsedilebilir. Teknolojinin etkin kullanılması, otizmli çocukların yaşam kalitelerini artırabilir ve bağımsız hayat sürmelerine katkı sağlayabilir. Ĕ̆itim teknolojilerinin etkin kullanılmasının eğitim sisteminin iyileştirilmesine katkıda bulunacağından yola çıkarak teknoloji entegrasyonuna yönelik pek çok araştırma yapılmıştır. Diğerlerinden farklı olarak, otizmli çocukların iletişim özellikle dil ve konuşma alanında yaşadıkları sıkıntılardan yola çıkarak bu araştırmada, her geçen gün otizmli çocuklarla daha fazla çalışmaya başlayan dil ve konuşma terapistlerinin özel gereksinimli çocuklar kapsamında otizmli çocukların eğitiminde teknoloji kullanımına yönelik görüşleri incelenmiştir. Böylelikle bu çocukların eğitimlerine yönelik gelişmelere katkıda bulunulacağı düşünülmüştür. Olgubilim deseninin kullanıldığı araştırmada yarı yapılandırılmış görüşmelerden yararlanılmıştır. Araştırmada elde edilen verilerin analizinde betimsel analiz tekniğinden yararlanılmıştır. Araştırmanın sonucunda, dil ve konuşma terapistlerinin otizmli çocukların eğitiminde teknoloji kullanımını destekledikleri ve terapistlerin çalıştıkları bireylerin özelliklerine uygun yöntem ve tercihleri belirlemesinin önemli olduğu belirlenmiştir.

Anahtar kelimeler: Dil ve konuşma terapisi, otizm, özel eğitim, eğitim teknolojileri

\section{How do speech-language pathologists view using educational technologies in autism?}

\footnotetext{
Abstract

Autism, which manifests itself with social interaction, communication and behavior problems, greatly affects the lives of individuals. Especially the delay in language development or the inability to speak at all, difficulties in starting, maintaining or ending conversations with other individuals are among the most common issues. Avoiding eye contact, not participating in peer games, avoiding interaction

Dr., Yıldız Teknik Üniversitesi, Yabancı Diller Yüksekokulu (İstanbul, Türkiye), sibelelverici@gmail.com, ORCID ID: o000-0002-6921-5013 [Araştırma makalesi, Makale kaylt tarihi: 25.10.2021-kabul tarihi: 20.12.2021; DOI: 10.29000/rumelide.1032442]

Dr. Öğr. Üyesi, Marmara Üniversitesi, Atatürk Eğitim Fakültesi, Özel Eğitim Bölümü (İstanbul, Türkiye), oktaytaymaz@gmail.com, ORCID ID: 0000-0002-7350-0909

Adres | Address

RumeliDE Dil ve Edebiyat Araşturmalar Dergisi $\quad$ RumeliDE Journal of Language and Literature Studies

Osmanağa Mahallesi, Mürver Çiçeği Sokak, No:14/8 Osmanağa Mahallesi, Mürver Çiçeği Sokak, No:14/8

Kadıköy - ISTANBUL / TÜRKIYE 34714 Kadıköy - ISTANBUL / TURKEY 34714

e-posta: editor@rumelide.com e-mail: editor@rumelide.com,

tel: +90 505 7958124, +90 2167730616 phone: +90 505 7958124, +90 2167730616
} 
with others, difficulties in interactive games and repetitive speech (echolalia) are among other communicative problems. Many approaches can be mentioned for the education of children diagnosed with autism. Effective use of technology may improve the quality of life of children with autism and contribute to their leading an independent life. Considering that the effective use of educational technologies will contribute to the improvement of the education system, many researches have been conducted on technology integration. Different from the others, based on the difficulties that children with autism experience in communication, especially language and speech, this study examines the opinions of speech and language therapists, who have started to work more and more with children with autism, on the use of technology in the education of children with autism within the scope of children with special needs. Thus, it is thought that these children will contribute to the development of their education. Phenomenological design was used in this study which benefited from semi-structured interviews. In the analyses of the data obtained in the study, descriptive analysis technique was used. At the end of the study, it was determined that speech and language therapists support the use of technology in the education of children with autism and that it is important for therapists to determine the methods and preferences suitable for the characteristics of the individuals they work with.

Keywords: Speech and language therapy, autism, special education, educational technology

\section{Giriş}

Çocuklar gelişim özellikleri bakımından birbirlerinden farklı özelliklere sahiptir ve bu farklı özellikler onları öğrenme özellikleri açısından da farklı yapar. Ancak kimi çocuk hızlı, kimi çocuk yavaş öğrense de bu farklılıklar çocuklar arasında ciddi sayllabilecek değişiklikler olarak görülmemektedir (Deniz, 2017; Şişman 2014). Otizmli çocuklarda sözel ya da motor tekrarlayıcı davranışlar, uyaranlara tepkisiz kalma sıkça görülen davranışsal sorunlar arasında yer alırken (Heward, 2012) sosyal etkileşim, iletişim, bilişsel beceriler ve odaklanma alanlarında sorun yaşadıkları bilinmektedir (Newell, Best, Gastgeb, Rump ve Strauss, 2010). Bu bağlamda, otizm bir engellilik grubu içerisinde yer almakta, otizmli çocuklar özel gereksinimli çocuklar olarak değerlendirilmekte ve aldıkları eğitim genel eğitim ortamlarında alınan eğitimlere göre farklılı göstermektedir

Otizmli çocukların bireysel farklılıklarına göre yapılan düzenlemeler onların gelişimleri açısından daha pozitif sonuçlar alınmasına yardımcı olabilmektedir. Erken çocukluktan itibaren özel gereksinimli çocukların eğitimlerinde değişik yaklaşımların kullanılması, özel gereksinimli çocukların da normal gelişim gösteren çocukların sahip olduğu haklara sahip olması önemlidir (Sarı, 2016). Yalnızca şimdi ve burada olarak değerlendirilemeyen dil ve konuşma, bireylerin iletişim ihtiyacının temelinde yatan kendini ve başkalarını anlamak ve anlatmak başkalarını etkilemek ve böylelikle iletişim kurmak için belirleyici bir role sahip olduğu görülmektedir. Bu bağlamda, otizmli bireylerin en çok sorun yaşadığı alanlardan biri dil ve konuşma olarak ortaya çlkmaktadır. Bu sorunun önüne geçebilmek için otizmli bireyler yoğun dil ve konuşma terapilerine ihtiyaç duymaktadır. Genel olarak nihai hedefi otizmli bireylerin gündelik hayatın içinde yer alması ve bunu yaparken bağımsız olması olarak tanımlanan özel eğitim alanı da özellikle son dönemlerde dil ve konuşma terapisi ile yakın bir ilişki halindedir denilebilir. Yine bu bağlamda, otizmli çocukların gelişimlerine katkıda bulunmak amacıyla eğitim teknolojilerinden daha fazla yararlanılmaya başlanmıştır.

Eğitim teknolojileri açısından bakıldığında, otizmli çocukların eğitiminde teknoloji kullanımı, özel eğitimde teknoloji kullanımına paralel olarak gelişmiş ve otizmli çocukların eğitiminde teknoloji 
kullanımını inceleyen pek çok araştırma yapılmıştır (Carlile, Reeve, Reeve ve DeBar, 2013; Murdock, Ganz ve Crittendon, 2013; Waddington vd., 2014). Otizmli çocukların eğitimleri sırasında teknolojik araç-gereçleri tercih ettikleri araştırma bulgularında yer almış, teknoloji-temelli eğitimlerin otizmli çocukların eğitimlerinde etkili olduğu belirtilmiştir Hourcade vd., 2012; Ergün Elverici, 2021). Otizmli çocukların eğitiminde sosyal etkileşim, iletişim ve öğrenme sorunlarının çözümü amacıyla yararlanılan yardımcı teknolojiler göz önüne alındığında (a) kâğıt, kalem, dosya gibi düşük maliyetli düşük düzey teknolojik araçlar olan, (b) tek tuşla ve genellikle pille çalışabilen orta düzey teknolojik araçlar olarak nitelendirilen saat çalarlar, ses kayıt cihazları vb. materyaller, (c) ileri düzey teknolojik araçlar olarak ise dizüstü ya da masaüstü bilgisayarlar ile tablet bilgisayarların kullanılmaktadır (Cramer, Hirano, Tentori, Yeganyan ve Hayes; 2011; Kientz, Goodwin, Hayes ve Abowd 2013). Otizm tanısı almış çocukların eğitiminde teknolojinin kullanılmasında amaç, bu çocukların normal gelişime sahip diğer akranlarına yakın, fiziksel ve zihinsel gelişim sağlamalarını destekleyerek yaşam kalitelerini artırmak, günlük yaşam becerilerini ve akademik becerilerini desteklemektir (Cavkaytar, 2013). Bunların yanı sıra teknolojik araç kullanımı ile desteklenmeleriyle süreç içinde öğrendikleri davranışların kalıcılığı da sağlanabilir (Ylldız, 2010).

Eğitimde teknoloji kullanımının artmasıyla özel eğitimde teknoloji kullanımı da artış göstermiş ve teknolojiye yapılan yatırımlar da buna paralel olarak artmış olsa da dil ve konuşma terapistlerinin teknoloji kullanımına yönelik düşüncelerini inceleyen çalışmalara ihtiyaç duyulduğu söylenebilir (Siyam, 2019). Dolayısıyla, dil ve konuşma terapistlerinin otizmli çocuklarla yapılan eğitimlerinde teknoloji kullanımına yönelik görüsslerinin belirlenmesinin önemli olduğu düşünülmektedir.

Araştırmada eğitim teknolojileri ifadesi öğretim teknolojileri, yardımcı teknolojiler ve eğitimde teknolojiye ait diğer ifadeleri içine alması nedeniyle üst kavram olarak kullanılmıştır.

\section{Araştırmanın amacı}

$\mathrm{Bu}$ araştırmanın genel amacı İstanbul ilinde otizmli çocuklarla çalışan dil ve konuşma terapistlerinin eğitimde teknoloji kullanımına yönelik görüş ve değerlendirmelerinin belirlenmesidir. Bu bağlamda terapistlerin çalışmalarıyla ilgili detaylı bilgi edinebilmek ve böylelikle otizmli çocuklarla yaptıkları çalışmalara yönelik daha derinlikli bir bakış açısı elde edebilmek için onların "normal" gelişim gösteren çocuklara yönelik çalışmalarına da araştırma kapsamında yer verilmiştir. Bu bağlamda, bu araştırma aşağıda verilen sorular kapsamında yürütülmüştür.

a) Dil ve konuşma terapistlerinin "normal" gelişim gösteren çocuklarla çalışırken izledikleri yola ilişkin görüşleri nelerdir?

b) Dil ve konuşma terapistlerinin otizmli çocuklara uyguladıkları dil ve konuşma terapisine ilişkin görüşleri nelerdir?

c) Dil ve konuşma terapistlerinin otizmli çocuklarla yapılan dil ve konuşma terapilerinde teknoloji kullanımına yönelik görüşleri nelerdir?

\section{Araştırmanın önemi}

Hızla gelişen dünyada yeni buluşların teknolojiye yansıması teknoloji kavramının daha geniş bir açıdan ele alınmasını sağlamıştır (Çoklar, Ergenekon ve Odabaşı, 2018). Eğitimde içerik hazırlama, materyal tasarımı ve değerlendirme gibi pek çok açıdan teknoloji kullanımı eğitimde daha fazla yer almaya 
başlamıştır. Bireysel farklılıkların en fazla göz önünde bulundurulması gereken alanlardan biri olan özel eğitim ve dolayısıyla otizmli çocuklar, en çok desteğe ihtiyaç duyan alanlardan biri olarak da değerlendirilebilir. Teknolojinin özel eğitimde kullanımının çeşitli amaçlarından bazıları özel gereksinimli çocukların akademik gelişimlerini desteklemek ve sosyal yaşama katılımlarını artırmak olarak sayılabilir (Ayres ve Cihak, 2010; Sula ve Spaho, 2014). Dil ve konuşma problemleri yaşayan çocuklara yönelik öğretmenlerin tutumları farklı araştırmalarda gözden geçirilerek incelenmiştir (Okalidou ve Kampanaros, 2001; Sadler, 2005). Son zamanlarda otizmli çocukların eğitiminde teknoloji kullanımına yönelik çalışmaların sayısında artış olsa da dil ve konuşma terapistlerinin bu konuya yönelik görüşlerini inceleyen çalışma sayısının çok az olduğu söylenebilir. Oysa, tıpkı eğitimde teknoloji kullanımının artması gibi otizmli çocukların dil ve konuşma terapistleri ile çalışmalarında da bir artış olduğundan yola çlkarak mevcut durumu belirlemenin gelecek araştırmalara yol göstermek açısından katkı sağlayacağı söylenebilir.

\section{Yöntem}

Bu bölümde araştırmanın modeli, evren ve örneklemi, araştırmanın yapıldığı grup, verilerin toplanması, veri toplama araçları ve geliştirme süreçleri, araştırmada kullanılan materyal ve uygulama süreci ile veri analizi teknikleri üzerinde durulmuştur.

\section{Araștırma modeli}

Nitel araştırma yönteminin kullanıldığı bu araştırmada olgubilim araştırma deseni kullanılmıştır. Olgubilim evrensel gerçekliğin, olayların veya varlıkların doğalarını betimleyebilmek için kişisel deneyimleri olgulara indirgemektir (Creswell ve Clark 2007). Olgubilim yaklaşımında araştırmacılar, belirli durumlarda insanların tepkilerini ve olaylara karşı bakış açılarını anlamaya çalışırlar (Bogdan ve Biklen, 2007, s. 25).

İnsan ve grup davranışlarının 'niçin'ini anlamaya yönelik araştırmalara nitel (qualitative) araştırma denir (Ergün, 2014). Nitel araştırmalarda, gözlem, görüşme ve doküman analizi gibi nitel veri toplama yöntemleri kullanılır. Nitel araştırmalarda veri analizi, ham verilerin toplanması, toplanan verilerin hazırlanıp organize edilmesi, organize edilen verilerin el veya bilgisayar yardımıyla kodlanması, kodların bir araya getirilerek temalara indirgenmesi, temaların betimlemeler ve birbirleri arasındaki ilişkilerin şekiller, çizgiler veya tartışma şeklinde sunulması basamaklarından oluşmaktadır (Creswell, 2018, s. 52).

\section{Betimsel analiz}

$\mathrm{Bu}$ çalışma nitel bir çalışma olarak tasarlanmış ve verilerin analizi için nitel araştırma yöntemlerinden birisi olan betimsel analiz kullanılmıştır. Betimsel analizlerde; katılımcıların davranışları, görüşleri, demografik özellikleri ve koşulları değerlendirilir. Genel olarak amaç var olan durumu olduğu gibi betimlemeye dayanmaktadır. Gay (1996) betimsel araştırmaları "şu anda ne oluyor?" sorusuna cevap aramak olarak tanımlamıştır Betimsel araştırmada elde edilen verilerin, araştırma konusu ile ilişkili olarak neleri ve hangi sonuçları ortaya koyduğu öne çımaktadır (Yıldırım ve Şimşek, 2013).

Betimsel araştırmalarda görüşme yapılarak yani sözlü iletişim yoluyla veri toplanır ve görüşmelerde bireylere çeşitli konulardaki bilgi, düşünce, tutum ve davranışları ile bunların olası nedenlerinin öğrenilmesi ile ilgili sorular yöneltilir (Karasar, 2008). Betimsel analizde amaç görüşme ve gözlem sonucu elde edilen verilerin düzenlenerek ve bulguların yorumlanarak okuyucuya sunulmasıdır. 


\section{Betimsel analizin güvenirliği ve geçerliği}

Nitel araştırma yöntemlerinin tümünde geçerlik ve güvenirliğin sağlanması önemlidir. Araştırmada elde edilen bulguların geçerliğini sağlamak amacıyla, bulgular yorumlanırken çalışmaya katılan gönüllülerin görüşme sorularına verdikleri cevaplardan doğrudan alıntılar yapılımıştır. Yıldırım ve Şimşek (2013) betimsel analizin kullanıldığı nitel araştırmalarda görüşülen bireylerin verdikleri yanıtlardan doğrudan alıntılar yapmanın ve bu alıntılardan yola çıkarak sonuçları açılamanın geçerliğin önemli ölçüde güçlendirdiğini belirtmiştir.

Çalışmamızın iç güvenirliği için pilot görüşmede yapılan kayıtlar iki farklı uzman tarafından değerlendirilmiştir. Dış güvenirliği sağlamak için ise görüşülen katılımcıların açık bir biçimde tanımlanması, veri toplanması ve analiz süreçlerinin detaylı olarak araştırma içerisinde anlatılması gerekmektedir (Yıldırım ve Şimşek, 2013).

\section{Veri toplama araçları}

Görüşme nitel araştırmalarda sıkça kullanılan bir tekniktir. Görüşme iki ya da daha fazla kişi arasında, bir kişinin yönlendirmesi ile görüşmeye katılan kişi ya da kişilerden bilgi elde etmek amacı ile yapılan amaçlı sohbet olarak tanımlanabilir (Bogdan, ve Biklen, 2007, s. 103). Araştırma verilerinin toplanması için yarı yapılandırılmış görüşme tekniği ile hazırlanmış görüşme soruları kullanılmıştır. Yarı yapılandırılmış görüşmelerde sorular daha geneldir ve görüşmecinin gerekirse daha fazla soru sormasına izin verir (Bryman, 2008). Sonuç olarak araştırmanın katılımcıları ile yarı yapılandırılmış görüşme formları kullanılarak derinlemesine görüşmeler gerçekleştirilmiştir. Sorular araştırmacı tarafından oluşturulduktan sonra birkaç kez kontrol edilmiş, özel eğitim ve / veya dil ve konuşma terapistliği alanında çalışan ve en az yüksek lisans derecesine sahip 2 uzman kişinin görüşleri alındıktan sonra 2 soruda değişiklik yapılmış, sorulara son şekli verilerek pilot görüşme için hazır hale getirilmiştir. Yine daha önceden belirtildiği üzere bu çalışmada eğitim teknolojileri üst kavram olarak kabul edilmiştir.

Araştırmada veri toplamak amacıyla belirlenen soruları test etmek için bir dil ve konuşma terapisti ile pilot görüşme yani ön görüşme yapılarak sorulara son şekli verilmiştir. Pilot görüşme yapılan terapist araştırma kapsamı dışında tutulmuştur. Aşağıda görüşme sorularının son şekli yer almaktadır:

\section{Görüş̧me soruları}

1. Normal gelişim gösteren çocuklarla dil gelişimi üzerine çalışırken kullandığınız yöntem ve teknikler nelerdir? Örnek verir misiniz?

2. Otizmli çocuklara yönelik dil ve konuşma terapisi hakkında ne düşünüyorsunuz? Bu konuyla ilişkili olarak neler söylersiniz?

Otizmli çocuklarla yapılan dil ve konuşma terapilerinde teknoloji kullanıyor musunuz? Neler yapıyorsunuz? Örnek verir misiniz?

\section{Evren ve örneklem/çalışma grubu/katılımcılar}

Katılımcıların belirlenmesinde amaçlı örnekleme çeşitlerinden biri olan ölçüt örnekleme kullanılmıştır. Ölçüt örnekleme, araştırma başlamadan önce belirlenen çeşitli ölçütleri karşlayan bireylerin

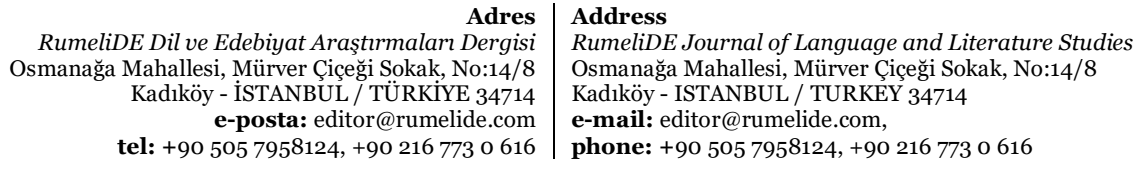


belirlenmesidir (Yıldırım ve Şimşek, 2013, s. 140). Dil ve konuşma terapisti olarak çalışan çok sayıda odyolog bulunduğu için, araştırmanın amacı göz önünde bulundurularak katılımcıların belirlenmesinde dil ve konuşma terapistlerinin otizmli çocuklarla çalışma deneyiminin olması ve dil ve konuşma terapisti olarak çalışabilmek için gereken yasal kriterleri karşılıyor olmaları ölçüt olarak alınmıştır. Araştırmanın örneklemini İstanbul ilindeki otizmli çocuklarla çalışan ve alanında uzman 10 dil ve konuşma terapisti oluşturmaktadır. Çalışmaya katılan ve farklı kurumlarda çalışan dil ve konuşma terapistleri görüşme öncesi gönüllü onam formunu imzalamışlardır.

Araştırmada katılımcılara görüşme sırasına uygun olarak K1, K2, K3 gibi kod isimler verilmiştir. Araştırmaya katılan dil ve konuşma terapistlerinin 6'sı kadın 4'ü erkektir. Mesleki kıdemleri 3 ile 21 yıl arasında değişmektedir. Yaş aralığı 25 ile 55 arasında değişen dil ve konuşma terapistlerinin 3’ü yüksek lisans 7'si lisans eğitimi almıştır. Dil ve konuşma terapistlerinden 6'si bir özel eğitim kurumunda çalışırken 4'ü kendi kurumlarında çalışmaktadır.

\section{Verilerin toplanması}

Araştırmaya ilişkin veriler 27.02.2021 ve 08.03.2021 tarihleri arasında katılımcllar ile görüşülerek toplanmıştır. Yüz yüze yapılan görüşmelerin tamamı dil ve konuşma terapistlerinin belirledikleri gün ve saatlerde kendi çalıştıkları kurumların dil ve konuşma servislerinde yapılmıştır. Görüşmeler pandemi dolayısıyla sadece yüz yüze değil aynı zamanda Zoom ve Google Meeting programları kullanılarak çevrimiçi görüşmeler şeklinde gerçekleşmiştir. Yüz yüze yapılan görüşme sayısı 6 , uzaktan yapılan görüşme sayısı 4'dür.

\section{Verilerin analizi}

Betimsel analizde amaç doğrudan alıntılarla görüşme yapılan bireylerin görüşlerini olduğu şekliyle net bir biçimde açıklamaktır. Böylelikle, betimsel analiz yoluyla, verilerin içinde saklı olabilecek gerçeklerin ortaya çlkarılmasına çalışılır. Bu amaç için izlenmesi gereken 4 aşama vardır; betimsel analiz için bir çerçeve oluşturulması, tematik çerçeveye göre verilerin işlenmesi, bulguların tanımlanması ve yorumlanması (Yıldırım ve Şimşek, 2013). Böylece, elde edilen veriler önce açık ve net bir şekilde betimlenir, betimlendikten sonra açıklanır, yorumlanır ve neden-sonuç ilişkileri kapsamında sonuçlar bulunur. Yorumlar temaların ilişkilendirilmesi, anlamlandırılması ve geleceğe yönelik tahminlerde bulunmayı da kapsamaktadır. Betimsel analizde "... veriler, daha önceden belirlenen temalara göre özetlenir ve yorumlanır.” (Ylldırım ve Şimşek, 2013, s. 256). Bu araştırmada betimsel analiz kapsamında, veri toplama aracında yer alan sorular tema olarak kabul edilerek incelenmiştir.

\section{Tematik çerçeveye göre verilerin işlenmesi}

Tüm görüşmelerin yazılı dökümünün kontrolü yapıldıktan sonra, terapistlerin görüşme sorularına verdikleri cevaplara göre temalara yönelik kodlar elde edilmiştir. Bu kodlar ilgili sorular altına sıralanmıştır. Daha sonra görüşme kodlama anahtarının güvenirliği belirlenmeye çalışılmıştır. Bunun için görüşmelerde alınan notların kopyaları ve kodlama anahtarı dil ve konuşma terapistliği ve özel eğitim alanlarından doktora derecesi ve nitel araştırma yöntemleri konusunda çalışma deneyimi olan iki uzmana verilmiştir. Görüşme notları ve kodlama anahtarları uzmanlar tarafından değerlendirilmiş ve görüşme kodlama anahtarı doldurulmuştur. Bu değerlendirme, görüşülen terapistlerin görüşüne uygun bulunan seçeneklerin uzmanlar tarafından görüşme kodlama anahtarı bölümünde işaretlenmesi ile yapılmıştır. Bu işaretlemeler sonucunda elde edilen sonuçlar karşılaştııldığında aynı işaretlenen

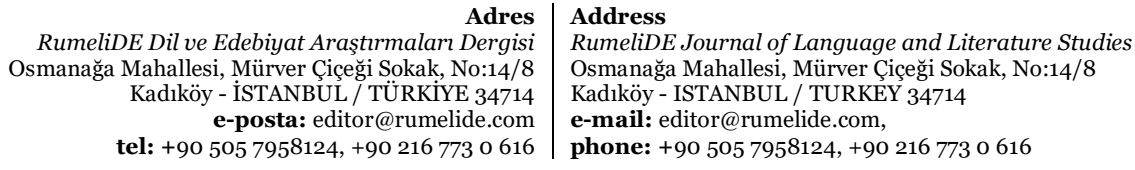


seçenekler "Görüş Birliği”, farklı seçenekler “Görüş Ayrılı̆̆ı" olarak tanımlanmıştır. Araştırmaya verilen cevapların güvenirlik hesaplamasında görüş birliği elde edilen kodlamalar, tüm kodlamaların toplamına bölünmüş ve yüz ile çarpılarak güvenirlik hesaplanmıştır. Tablo 1'de görüşme kodlama anahtarında yer alan soruların güvenirlik yüzdeleri verilmiştir.

Tablo 1 Görüşme kodlama anahtarında yer alan soruların güvenirlik yüzdesi

\begin{tabular}{ll}
\hline Sorular & Güvenirlik Yüzdeleri \\
\hline Soru 1 & $\% 74$ \\
Soru 2 & $\% 81$ \\
Soru 3 & $\% 77$ \\
\hline Güvenirlik Ortalaması & $\mathbf{\% 7 7 , 3 3}$ \\
\hline
\end{tabular}

Görüşme kodlama anahtarının güvenirlik çalışmasındaki en düşük güvenirlik 1'inci soruda \%74 ve en yüksek güvenirlik 2'inci soruda \%81 olarak hesaplanmıştır. Bu üç sorunun güvenirlik ortalaması ise \%74 olarak hesaplanmıştır.

\section{Bulgular}

Bu araştırmada betimsel analiz kapsamında, veri toplama aracında yer alan soruların tema olarak kabul edilerek incelendiği belirtilmişti. Elde edilen bulgular, aynı soruların sırası göz önünde bulundurularak sunulmuştur. Bu bağlamda, araştırmanın bulgularını oluşturan ve görüşme sorularına istinaden çerçevelendirilen ana başlıklar şu şekildedir:

1. Normal gelişim gösteren çocuklarla çalışırken kullanılan yöntem ve teknikler

2. Otizmli çocuklara yönelik dil ve konuşma terapisi

3. Otizmli çocuklara yönelik dil ve konuşma terapisinde teknoloji kullanımı

Bu başlıklara ait bulgular aktarılmadan önce bulunan frekanslar hesaplanmış ve bu frekanslara göre frekansı yüksek olan kodlara ilişkin örnekler ilgili başlıklar altında verilmiştir. Ancak hesaplamalarda frekansı düşük olmasına rağmen bazı kodlara araştırmanın bulgularını zenginleştirebileceği düşünülerek bazı temalar altında yer alan kategorilerde yer verilmiştir.

\section{Normal gelişim gösteren çocuklarla dil gelişimi üzerine çalışırken kullanılan yöntem ve teknikler}

Dil ve konuşma terapistlerine seanslarında normal gelişim gösteren çocuklarla çalışırken kullandıkları yöntem ve teknikleri belirlemek için "Normal gelişim gösteren çocuklarla çalışırken kullandığınız yöntem ve teknikler nelerdir? Örnek verir misiniz?” sorusu yöneltilmiştir. Görüşme yapılan dil ve konuşma terapistlerinin bu soruya verdikleri yanıtlara yönelik kodlar ve frekans dağılımları, yöntemler için Tablo 2 ve terapistlerin kulandıkları teknikler için Tablo 3’te gösterilmiştir.

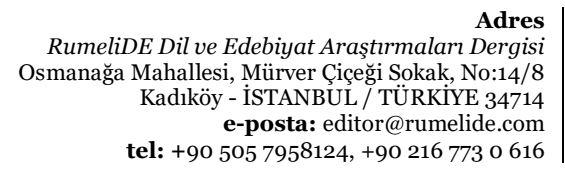

Adres
RumeliDE Dil ve Edebiyat Araşttrmaları Dergisi

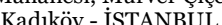
tel: +90 505 7958124, +902167730616
Address

RumeliDE Journal of Language and Literature Studies

Osmanağa Mahallesi, Mürver Çiçeği Sokak, No:14/8

Kadıköy - ISTANBUL / TURKEY 34714

e-mail: editor@rumelide.com,

phone: +90 $5057958124,+902167730616$ 
Tablo 2 Normal gelişim gösteren çocuklarla çalışırken kullanılan yöntemler

\begin{tabular}{ll}
\hline Yöntemler (yaklaşımlar) & f \\
\hline Öğrenci merkezli yaklaşımlar & 8 \\
Karma yaklaşımlar & 9 \\
Dil ve konuşma terapisti merkezli yaklaşımlar & 6 \\
\hline Toplam & $\mathbf{2 3}$ \\
\hline
\end{tabular}

Tablo 2'de görüldüğü gibi yöntemler kategorisinde elde edilen kodlarda 8 terapist öğrenci merkezli yaklaşımlar, 9 terapist karma yaklaşımlar, 6 terapist dil ve konuşma terapisti merkezli yaklaşımları takip ettiklerini bildirmiştir. Toplamda 3 farklı yaklaşım üzerinde durulmuştur. Bu konuda K2 ve K3 kodlu terapistlerin görüşleri aşağıda verilmiştir.

K2: Üniversitede öğrendiğimiz yöntemlerin büyük bölümü aslında aynı gibi. Ben bu yüzden karma yaklaşımların daha doğru olduğunu düşünüyorum. Kuruma gelen çocukların büyük bölümü RAM raporu ve oradaki danışmanların çalışma programı ile geliyor. Kurum olarak bizim de inceleme ve önerilerimiz oluyor. Son olarak ben çalışırken çocuğa ve kendime uygun yöntemleri belirliyorum. Bu uyumu en çok karşllayan karma yöntem gibi duruyor.

K3: Kendi yerimizi açana kadar çalıştığım kurumun bize sağladığı materyal ve programı kullanırdık. Çoğu zaman aslında özel eğitim uygulamalarını desteklediğimiz ve aslında dil ve konuşma terapisi alanına tam uyumlu diyemeyeceğimiz çalışmalar yapmak zorunda kaldık. Hazır bir kek kalıbında hem kek hem puding yaptık gibi. Çocuğa uymadı̆̆ı gibi terapiste de uymuyordu. Bizim alanımızda kabul gören 3 yaklaşım vardır. Terapist merkezli, öğrenci merkezli ve ikisinin karışımı gibi duran karma yaklaşım. Kendini ön plana çıkarmak isteyen terapistler her şeyi ben bilirim demek istercesine terapist merkezli olanı seçer. Kimisi de veliye hoş görünmek adına öğrenci merkezli olanı seçer. Hangisi seçilirse seçilsin yöntemsizlikten iyidir. Asıl önemli olan yönteme uygun teknikleri uygulamaktır.

Tablo 2'den anlaşılacağı gibi dil ve konuşma terapistlerinin kullandığını belirttiği yöntemler (yaklaşımlar) kategorisinde 3 kod mevcut bir yöntemi işaret eden kodlar olarak ortaya çlkmaktadır. İşaret edilen yöntemler dil ve konuşma terapistlerinin normal gelişim gösteren çocuklar için kullandığı yöntemler içerisinde ve tutarlıdır.

Tablo 3 Normal gelişim gösteren çocuklarla çalışırken kullanılan teknikler

\begin{tabular}{|c|c|}
\hline Teknikler & f \\
\hline Kendi kendine konuşma & 4 \\
\hline Paralel konuşma & 4 \\
\hline Taklit & 4 \\
\hline Genişletme & 4 \\
\hline Uzatma & 4 \\
\hline Geliştir ve parçala & 4 \\
\hline Cümlenin yeniden düzenlenmesi & 4 \\
\hline Öğrencinin üretemediği sesbiriminin ayırt edilmesi & 6 \\
\hline Doğru ses üretilmesine odaklanma & 6 \\
\hline Alıştırma yapma (drill) & 8 \\
\hline Alıştırma oyunu (drill play) & 8 \\
\hline Biçimlendirme (modeling) & 8 \\
\hline Toplam & 64 \\
\hline $\begin{array}{r}\text { Adres } \\
\text { RumeliDE Dil ve Edebiyat Araşttrmaları Dergisi } \\
\text { Osmanağa Mahallesi, Mürver Ciçeği Sokak, No:14/8 } \\
\text { Kadıköy - İSTANBUL / TÜRKIYY } 34714 \\
\text { e-posta: editor@rumelide.com } \\
\text { tel: +90 505 7958124, +90 } 216773 \text { o } 616\end{array}$ & $\begin{array}{l}\text { Address } \\
\text { RumeliDE Journal of Language and Literature Studies } \\
\text { Osmanağa Mahallesi, Mürver Cicceği Sokak, No:14/8 } \\
\text { Kadıköy - ISTANBUL / TURKEY } 34714 \\
\text { e-mail: editor@ @umelide.com, } \\
\text { phone: +90 505 7958124, +90 } 216773 \text { o } 616\end{array}$ \\
\hline
\end{tabular}


Tablo 3’te görüldüğü gibi görüşülen 10 terapist 12 farklı teknikten bahsetmiştir. Kullanmış oldukları tekniklerle ilgili 4 terapist kendi kendine konuşma, paralel konuşma, taklit, genişletme, uzatma, geliştir ve parçala ve cümlenin yeniden düzenlenmesi, 6 terapist öğrencinin üretemediği sesbirimin ayırt edilmesi ve doğru ses üretilmesine odaklanma, ve 8 terapist alıştırma yapma (drill), alıştırma oyunu (drill play) ve biçimlendirme (modeling) kodlarını kullanmışlardır. Bu konuda $\mathrm{K}_{5}$ ve $\mathrm{K}_{7}$ kodlu terapistlerin görüşleri aşağıda verilmiştir.

K5: Ben bol bol taklit çalışması yaptırıyorum. Neredeyse her seansta kullandığım bir teknik bu. Burada örnek vermeye gerek yok herhalde. Bu öğrenci merkezli yöntemin tekniklerinden birisidir. Taklitle beraber kullandığım diğer bir teknikte paralel konuşma. Özellikle okuma yazma bilen çocuklarla bir metni aynı anda okuyoruz. Başka teknikler de var. İsim olarak vermek gerekirse genişletme, uzatma, geliştirme, parçalama ve cümlenin yeniden düzenlenmesi gibi teknikleri sayabilirim. Karma yaklaşım kullandığım da oluyor. Aslında her türlü tekniği gereken yerde kullandığım için yöntemler yerine tekniklerden konuşmak daha mantıklı galiba. Mesela bu karma yöntemde önce öğrencinin üretemediği sesbirimini belirliyoruz sonra da doğru ses üretilmesine odaklanıyoruz. Çocuğu gördükten sonra bu teknikler yavaş yavaş kafamızda şekilleniyor. Ben hep şu tekniği kullanırım diyen terapist yalan söyler bence.

K7: Ben karma yaklaşımın tekniklerini kullanmayı doğru buluyorum. Ama kitaplara bakarsanız sanki sadece 2 teknik varmış gibi gözüküyor. Ama adı üstünde karma yaklaşım işe yarayacağını düşündüğünüz her tekniği içerebilir. Öncelikle bu anlattıklarım normal gelişim gösteren çocuklar için geçerli. Diğer çocuklarla çalışırken özel eğitim öğretmenlerinden görüş alıyoruz ve çoğu zaman ben onların yaptıklarına destek oluyorum. Normal gelişim gösteren çocuklarda önce öğrencinin üretemediği sesbirimini belirlemeye çalışıyoruz. Bazen ben yapıyorum bazen de kurumda çalışan diğer arkadaşlarla beraber yapıyoruz. Sonra bu seslerin doğru çıkarılmasına odaklanıyoruz. Bu doğru çıkartma etkinlikleri için kurum içerisinde öğrenci merkezli teknikleri, ev çalışmalarında terapist merkezli çalışmaları tercih ediyorum. Bunun için çalışmalarımı video ile veliye veriyorum. Onlar da ev çalışmalarını çekip bana getiriyor.

Tablo 3’ten de anlaşılacağı gibi dil ve konuşma terapistlerinin kullandığını belirttiği tekniklerden ortaya çıkan 12 kod mevcut bir tekniği işaret eden kodlar olarak ortaya çıkmaktadır. İşaret edilen teknikler dil ve konuşma terapistlerinin normal gelişim gösteren çocuklar için kullandı̆̆ yöntemler için kullanılan tekniklerle tutarlıdır.

\section{Otizmli çocuklara yönelik dil ve konuşma terapisi}

Dil ve konuşma terapistlerinin otizmli çocuklara yönelik dil ve konuşma terapisi hakkındaki görüşlerini belirlemek için "Otizmli çocuklara yönelik dil ve konuşma terapisi hakkında ne düşünüyorsunuz? Bu konuyla ilişkili olarak neler söylersiniz?” sorusu yöneltilmiştir. Görüşme yapılan dil ve konuşma terapistlerinin bu soruya verdikleri yanıtlardan elde edilen kodlar ve frekans dağılımları Tablo 4'te gösterilmiştir.

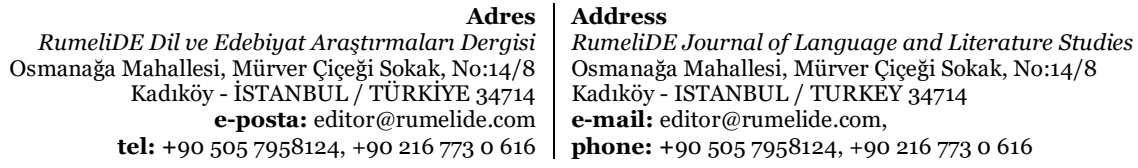

RumeliDE Dil ve Edebiyat Araşttrmaları Dergisi tel: +90 505 7958124, +90 2167730616

phone: +90 505 7958124, +90 2167730616 
Tablo 4 Otizmli çocuklara yönelik dil ve konuşma terapisi

\begin{tabular}{ll}
\hline Otizmli çocuklara yönelik dil ve konuşma terapisi & $\mathrm{f}$ \\
\hline Birlikte çalışılmalı & 6 \\
Ekonomik değil & 6 \\
Oldukça zahmetli & 5 \\
Uzun dönem çalışlmalı & 5 \\
Özel durumlarda gerekli & 5 \\
Kesinlikle olmalı & 4 \\
Gerekli & 3 \\
Her çocukla olmuyor & 3 \\
\hline Toplam & $\mathbf{3 4}$ \\
\hline
\end{tabular}

Tablo 4’te görüldüğü gibi 6 terapist birlikte çalışılması gerektiğini ve ekonomik olmadığını, 5 terapist oldukça zahmetli olduğu, uzun dönem çalışılması gerektiği ve özel durumlarda çalışılması gerektiği, 4 terapist kesinlikle olması gerektiği ve 3 terapist gerekli olduğunu ve her çocukta olmadığını bildirmiştir. $\mathrm{Bu}$ konuda K1 ve K9 kodlu terapistlerin görüşleri aşağıda verilmiştir.

K1: Özel Eğitim alanında yüksek lisans yaptım. Ben birlikte çalışılması gerektiğini düşünüyorum. Kuruma gelen çocukların büyük bölümü özel eğitim için geliyor. Dil ve konuşma terapistleri için gelen çocuk sayısının belki 20 katı. Bu öğrencilerin büyük bölümü otizm tanılı. Bildiğiniz gibi otizmli çocukların yaşadığı en büyük sıkıntılardan biri gecikmiş konuşma ya da hiç konuşmama. Pek çok uygulama bu çocuklarda davranışa ve sosyalleşmeye yönelik. Bazı özel eğitimciler alıcı dil ve ifade edici dil gelişimi üzerine çalışıyor. Oldukça da başarılılar ancak gecikmiş konuşma sonucunda doğru ses ve tonlama sorunu sosyalleşmede sıkıntı yaratabiliyor. Biz bu noktada devreye giriyoruz. Ancak bizim terapilerimiz bazen bu çocuklara ulaşma noktasında yeterli olmuyor. Umarım terapist arkadaşlar kırılmaz. Böyle durumlarda ya terapist özel eğitim konusunda eğitim alacak ya da özel eğitim uzmanları ile beraber çalışacak.

K9: Her otizmli çocukta olmalı mı emin değilim. Her çocukta olmuyor diye biliyorum. Otizmli çocuklar konusunda çok donanımlı değilim ama özel eğitim uzmanları ile birlikte çalışılabilir diye düşünüyorum. Bu zor bir süreç ve uzun bir çalışma gerektirir. Kurum için de veli için de ekonomik olmayabilir. Bir öğrenci için bir terapist bir de özel eğitimci. Belki bir hafta terapi bir hafta eğitim olabilir ama gerekli diye düşünüyorum.

Tablo 4’ten de anlaşılacağı üzere dil ve konuşma terapistlerinin büyük bölümü otizmli çocuklarla dil terapisinin gerekli olduğunu ancak ekonomik olarak zor olduğunu belirtmiştir.

\section{Otizmli çocuklarla yapılan dil ve konuşma terapilerinde kullanılan teknolojiler}

Dil ve konuşma terapistlerinin otizmli çocuklarla yapılan dil ve konuşma terapilerinde kullanılan teknolojiler üzerine görüşlerini belirlemek için "Otizmli çocuklarla yapılan dil ve konuşma terapilerinde teknoloji kullanıyor musunuz? Neler yapıyorsunuz? Örnek verir misiniz?” sorusu yöneltilmiştir. Görüşme yapılan dil ve konuşma terapistlerinin bu soruya verdikleri yanıtlardan elde edilen kodlar ve frekans dağılımları Tablo 5’te gösterilmiştir.

Tablo 5 Otizmli çocuklarla yapılan dil ve konuşma terapilerinde kullanılan teknolojiler

\begin{tabular}{|c|c|c|}
\hline \multicolumn{2}{|c|}{ Otizmli çocuklarla yapılan dil ve konuşma terapilerinde kullanılan teknolojiler } & $\mathrm{f}$ \\
\hline \multicolumn{2}{|c|}{ İşitsel ve görsel materyal } & 10 \\
\hline \multicolumn{2}{|l|}{ Ses kayıt teknolojileri } & 10 \\
\hline \multicolumn{2}{|l|}{ Otizm için tablet uygulamaları } & 10 \\
\hline $\begin{array}{r}\text { Adres } \\
\text { RumeliDE Dil ve Edebiyat Araştrmaları Dergisi } \\
\text { Osmanağa Mahallesi, Mürver Ciçeğ Sokak, No:14/8 } \\
\text { Kadıköy - İTANBUL / TÜRKIYE } 34714 \\
\text { e-posta: editor@rumelide.com } \\
\text { tel: }+90 \text { 505 7958124, +90 216 773 o } 616\end{array}$ & $\begin{array}{l}\text { Address } \\
\text { RumeliDE Journal of Language and Literatu } \\
\text { Osmanağa Mahallesi, Mürver Ciçeği Sokak, N } \\
\text { Kadiköy - ISTANBUL / TURKEY } 34714 \\
\text { e-mail: editor@rumelide.com, } \\
\text { phone: +90 505 7958124, +90 } 216773 \text { o } 616\end{array}$ & \\
\hline
\end{tabular}




\begin{tabular}{ll}
\hline Video model & 7 \\
Hikâye ve masal programları & 7 \\
Veli iletişimi & 7 \\
Gelişim videoları & 6 \\
Etkinlik çizelgesi & 5 \\
Göz teması & 4 \\
\hline Toplam & $\mathbf{6 6}$ \\
\hline
\end{tabular}

Tablo 5’te görüldüğü gibi 10 terapist işitsel ve görsel materyal olarak, ses kayıt teknolojileri olarak kullandığını ve otizme yönelik tablet uygulamaları olduğunu, 7 terapist video model olarak, hikâye ve masal programları olarak ve veli iletişimi için kullandığını, 6 terapist çocukların gelişim videolarını aldığını, 5 terapist etkinlik çizelgesi olarak kullandığını ve 4 terapist göz teması için kullandığını bildirmiştir. Bu konuda K7 ve K8 kodlu terapistlerin görüşleri aşağıda verilmiştir.

K7: Teknolojik gelişimleri özel eğitimde kullandığımızı söylemiştik zaten. Ĕğer konu sadece otizm alanı ise söylemem gerekir ki galiba en fazla gelişim bu alanda. Engel gruplarında ortopedik pek çok cihaz teknoloji sayesinde gelişti ama otizm ve otizmli çocukların konuşmasına yönelik cihaz yerine telefon ve tabletlerde kullanılan uygulamalar gelişti. Bunun nedeni otizmde yaşanılan engellilik durumunun eğitimle aşılabileceğinin bilinmesi ve bu eğitimin kesintisiz her ortamda aynı şekilde yapılabilmesi için ortak görüş. Eğitimci ve terapistler açısından bakıldığında yaptığımız çalışmalara gerçekten büyük destek sağlayan bu teknolojiler veliler için ciddi ekonomik kazanç olabiliyor. Tamam tablet ve telefon ucuz değil. Pek çok uygulama ücretli, ama veli eğer çocuğun gelişimi için haftada en az 30 saat eğitim alması gerektiğini biliyor ve hesabını buna göre yapıyorsa teknolojinin çok daha ucuza geldiğini görebilir. Biraz konu dışına çıktım ama örnek vermem gerekirse aynı cihazla, video çekebilir, ses ve resim çalışması yapabilir, eğitici uygulamaları kullanabilir ve iletişim kurabilirsiniz.

K8: Benim en çok kullandığım ses uygulamaları. Voice-up uygulaması sayesinde fısıltı ve incecik ses tonu ile konuşmaya çalışan çocukların seslerinin normale yakın çıkmaya başladığını gördüm. Bu onlarda özgüvenin artmasını sağladı. Daha sonra kullandığım sadece normal video çekme özelliği. Çocuklara kendi video ve seslerini kaydedip dinletiyorum. Kendi resimli ve sesli resim kartlarını oluşturuyorum. Taşınabilir olduğu için her yerde kullanıyorlar. Bir de sadece otizme yönelik tablet ve telefon uygulamaları var. Bazıları ücretli ama ücretsiz olan ve çok kullanışlı olan uygulamalar da var.

Görüşme sorusuna verilen cevaplardan anlaşllacağı üzere terapistlerin tamamının teknoloji desteği olarak tablet ya da akıllı telefon gibi cihazların ses ve görüntü kaydı özelliğini kullandığı görülmektedir. Özellikle uygulama marketlerinde satılan otizm destek uygulamalarının terapistlerin tamamı tarafindan kullanıldığı görülmektedir. Bu soruda elde edilen cevaplardan da anlaşılacağı gibi terapistlerin teknoloji olarak ortak algıları teknolojik araç kullanımıdır. Eğitim teknolojileri araç olarak düşünüldüğünde öğrenmeyi kolaylaştıran, öğrenme kazanımlarını artıran, içerisinde akıllı tahtadan tablet bilgisayara, öğrenme yönetim sistemine kadar her şeyi alan herhangi bir araç, kaynak veya uygulama olarak tanımlanmaktadır (Parkman, Litz ve Gromik, 2018: 1254). Günümüze kadar farklı tanımları yapılmış olan eğitim teknolojisi literatürde öğretim teknolojisi, yardımcı teknolojiler gibi farklı ifadelerle kullanılmıştır. Eğitim teknolojisi, çeşitli şekillerde tanımlanmaya devam etmektedir. Halen geçerliğini koruyan bir tanımda eğitim teknolojisi, bilimsel verilere dayanan sistemli bir plan dahilinde yetişmiş insan gücü ile diğer kaynakları belli yöntem ve tekniklerle bir araya getiren, böylelikle ulaşılan sonuçları değerlendirerek belirlenmiş eğitim amaçlarına ulaşma süreci olarak yer almaktadır (Demirel, 2001, s. 44-45). Bu bağlamda eğitim teknolojisi yalnızca araç gereç olarak değil, araç gereci de içine alan büyük bir sistem olarak değerlendirilmeli ve araç kullanımı amaç olarak görülmemelidir denilebilir.

\section{Tartışma ve sonuç}

Adres

RumeliDE Dil ve Edebiyat Araştırmaları Dergis Osmanağa Mahallesi, Mürver Çiçeği Sokak, No:14/8 Kadıköy - ISTANBUL / TÜRKIYE 34714 e-posta: editor@rumelide.com tel: +90 $5057958124,+902167730616$
Address

RumeliDE Journal of Language and Literature Studies

Osmanağa Mahallesi, Mürver Çiçeği Sokak, No:14/8

Kadıköy - ISTANBUL / TURKEY 34714

e-mail: editor@rumelide.com,

phone: +90 5057958124, +90 2167730616 
Araştırma özel eğitim kurumlarında ve özel dil ve konuşma terapi merkezlerinde görev yapan dil ve konuşma terapistlerinin otizmli çocukların eğitiminde teknoloji kullanımına yönelik görüşleri incelenmiştir. Bu bölümde bulgulardan elde edilen veriler tartışılmıştır.

Araştırmaya katılan dil ve konuşma terapistlerinin 8’i kullanılan yaklaşımlarla ilgili olarak toplamda 3 farklı yöntemden bahsetmiştir. Bu yöntem ya da yaklaşımlar; öğrenci merkezli yaklaşımlar, karma yaklaşımlar ve terapist merkezli yaklaşımlardır ve dil ve konuşma sorunu yaşayan bireylerin gelişimlerini sağlamak üzere destekleyici aşamaları belirlemek ve düzenli bir şekilde destek olmak için kullanılmaktadır (Paul ve Norbury, 2012). Çalışmaya katılan terapistler kullandıkları teknikler olarak; kendi kendine konuşma, paralel konuşma, taklit, genişletme, uzatma, geliştirme ve parçalama, cümlenin yeniden düzenlenmesi, öğrencinin üretemediği sesbirimin ayırt edilmesi, doğru ses üretilmesine odaklanma, alı̧stırma yapma (drill), alıştırma oyunu (drill play) ve biçimlendirme (modeling) alt temalarını kullanmışlardır. Ayrıca terapistler görüşmeler sırasında dil ve konuşma terapisinde dil terapisi yaklaşımlarının çocuk merkezli yaklaşımlar ile terapist merkezli yaklaşımlar arasında çeşitliliğe sahip olduğunu bildirmiştir. Alan yazında bu konu ile ilgili araştırmalarda da öğrenciler için uygulanacak dil ve konuşma terapisinin ekonomik ve verimli olması için seçilecek yaklaşımın öğrencinin bireysel ihtiyaçlarını karşılayabilecek özellikte olması gerektiği belirtilmektedir (Paul, ve Norbury, 2012; s. 68).Alt temalarda ortaya çlkan teknikler dil ve konuşma terapilerinde kullanılan tekniklerle uyuşmaktadır. Ayrıca araştırma sorusunun ilk bölümünü oluşturan kullanılan yöntemler ve kullanılan teknikler birbiri ile örtüşmektedir. Dil ve konuşma terapistlerinin kullandıklarını söyledikleri teknikler ve tercih ettiklerini söyledikleri yöntemler birbiri ile uyumludur. Eğitimin her alanında olduğu gibi, terapistlerin de çalıştıkları bireylerin özelliklerine uygun yöntem ve tercihleri belirlemesi sonuca ulaşmada daha güvenli bir yol oluşturmalarını sağlamada önemlidir. Dil ve konuşma terapistlerinin, değerlendirme ve terapi sürecini yapılandırabilmesi için bu bozukluk ile ilgili doğru bilgiye sahip olması gerekmektedir (Hedge, 2008b; Shipley ve McAfee, 2015)

Dil ve konuşma terapistlerinin otizmli çocuklara yönelik dil ve konuşma terapisi hakkındaki görüşlerini belirlemek için sorulan soruya verdikleri cevaplardan daha önce bu konuda eğitim almalarına rağmen çalışmalar öncesinde otizmli çocukların özel eğitim uzmanlarından ön hazırlık alarak gelmelerinin daha faydalı olduğu görüşü ön plana çıkmaktadır. Burada dikkat çeken, bu iki alanın ortak çalışmasının faydalı olduğu ancak ekonomik olarak veliyi zorlayabileceğidir. Görüşmelerde ortaya çıan sonuçlardan birisi olarak dil ve konuşma terapistlerinin özel gereksinimli bireyler iletişim, dil ve konuşma becerilerinde çeşitli sorunlar yaşayabileceğinin farkında olmasıdır. Alan yazında da dil ve konuşmada yaşanan güçlüklere bağlı olarak özel gereksinimli öğrencilerin akademik ve sosyal becerilerde sorunlarla karşılaşabilecekleri vurgulanmaktadır (Cole ve Flexer, 2007, s. 37; Harrington, DesJardin ve Shea, 2010, s. 50-62; Marschark, Rhoten ve Fabich, 2007, s. 269-281). Araştırmaya katılan terapistler yaşanabilecek bu güçlüklerin azaltılması ve ortadan kaldırılabilmesi için öğrencilere ihtiyaç ve özel gereksinimlerine uygun destek hizmetlerinin sunulmasının önemli olduğunu belirtmektedir. Alan yazında yapılan incelemelerde Topbaş, Konrot ve Başal (1996) hizmet götürülmeye çalışlan bozukluk gruplarını, kekemelik (\%19), gecikmiş konuşma (\%16), artikülasyon bozukluğu (\%15), ses bozukluğu (\%12), özel öğrenme güçlüğü (\%11), gelişimsel disfazi (\%8), edinilmiş dil bozukluğu-afazi (\%5), dizartri (\%5), apraksi (\%4), serebral palsi (\%4) ve duygusal/davranışsal bozukluklar (\%1) olarak rapor etmiştir, çalışmamızda sayısal olarak bu sıklık ele alınmamasına rağmen otizme bağlı gecikmiş dil ve konuşma bozukluğunun daha yüksek oranda çalışıldığı görülmektedir. Ayrıca araştırma sırasında öne çıkan bulgulardan birisi dil ve konuşma terapistlerinin otizmli çocuklarla karşılaşma oranında görülen artışın ifade edilmesidir.

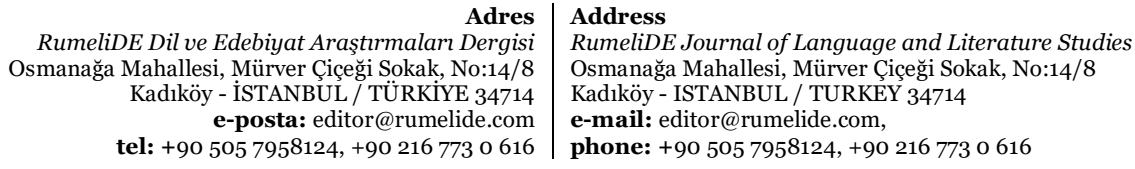


Dil ve konuşma terapistlerinin özel eğitim alanında özellikle otizmli çocuklarla yaptıkları dil ve konuşma terapilerinde kullandıkları teknolojiler üzerine görüşlerini belirlemek üzere sorulan soruya terapistler yalnızca teknolojik araçları düşünerek cevap vermiş ve terapistlerin tamamı işitsel ve görsel materyal olarak ve ses kayıt teknolojileri olarak kullandıklarını söylemişlerdir. Özellikle otizm için kullanılan tablet uygulamaları olduğunu ve bu uygulamaların hem tablette hem de cep telefonunda kullanılabildiği için her yerde ve her zaman çocukların elinin altında olmasının kolaylığı dile getirilmiştir. Ayrıca dil terapistleri kullandıkları yardımcı teknolojileri sadece konu anlatmak ve terapi sırasında eğitim materyali olarak kullanmadıklarını, buna ek olarak pekiştireç olarak faydalandıklarını belirtmişlerdir. Bu sonuç Özdamar (2016) ile Eldeniz Çetin ve Geçal'ın (2017) bulguları ile örtüşmektedir.

\section{Öneriler}

Araştırmada elde edilen bulgular ve sonuçlara göre bazı önerilerde bulunulmuştur.

- Dil ve konuşma terapistleri alanlarında geçerli yöntem ve teknikler hakkında daha sık hatırlatma eğitimleri alabilirler ve farklı yöntem ve teknikleri uygulayabilmeleri konusunda teşvik edilebilirler.

- Dil ve konuşma terapistlerine otizm alanında özellikle otizmli çocukların konuşma eğitimleri konularında üniversite düzeyinde ve üniversite sonrasında hizmetiçi programlarla eğitim verilebilir.

- Dil ve konuşma terapistlerine eğitim teknolojilerinin ne olduğu ve eğitimde teknoloji kullanımının nasıl olması gerektiği konusunda üniversite düzeyinde eğitim verilebilir. Mezun terapistler hizmetiçi eğitimlerle desteklenebilir.

- Araştırma özel eğitim ve konuşma terapisi alanlarında kullanılan belirli teknolojik uygulamaların ve yazılımların etkililiği üzerine yapılabilir.

\section{Araștırmanın sınırlılıkları}

Araştırma 2020-2021 eğitim öğretim yılında İstanbul'da gerek kendi danışmanlık firmasında gerekse özel eğitim ve rehabilitasyon merkezlerinde otizmli çocuklarla çalışan 10 dil ve konuşma terapistiyle sınırlıdır. Araştırma ayrıca otizmli çocuklarla çalışan dil ve konuşma terapistlerinin otizmli çocuklarda teknoloji kullanımına yönelik görüşlerini belirlemek üzere oluşturulan görüşme soruları ile sınırlıdır. COVID-19 salgını nedeniyle dört görüşmenin yüz yüze değil uzaktan yapılması da araştırmanın sinırlılıkları arasında sayılabilir.

\section{Kaynakça}

Ayres, K., \& Cihak, D. (2010). Computer-and video-based instruction of food-preparation skills: Acquisition, generalization, and maintenance. Intellectual and developmental disabilities, 48(3), 195-208.

Bogdan, R. C. \& Biklen, S. K. (2007). Qualitative resarch for education: An introdaction to theory and methods (5. Basim). USA: Pearson.

Bryman, A. (2008). Of methods and methodology. Qualitative Research in Organizations and Management: An International Journal, 159-168.

Carlile, K., Reeve, S., Reeve, K. \& DeBar, R. (2013). Using activity schedules on the iPod touch to teach leisure skills to children with autism. Education and Treatment of Children, 33-57

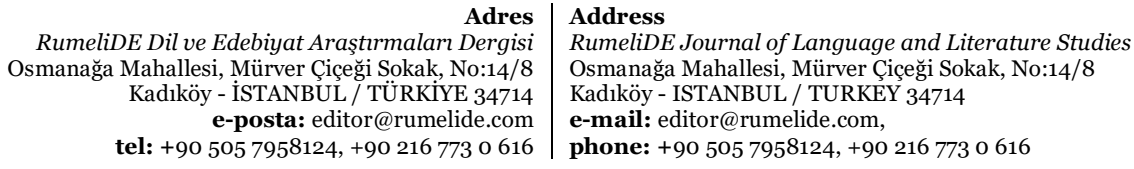


Cavkaytar, A. (2013). Özel Ĕ̆itime Gereksinimi Olan Öğrenciler ve Özel Eğitim (7. Baskı). Ankara: Pegem Akademi.

Cole, E. B., ve Flexer, C. A. (2007). Children with hearing loss: Developing listening and talking, birth to six. San Diego: Plural Pub.

Cramer, M., Hirano, S. H., Tentori, M., Yeganyan, M. T. \& Hayes, G. R. (2011).Classroom-based assistive technology: collective use of interactive visual schedules by students with autism. In CHI (pp. 1-10).

Creswell, J. W. (2018). Nitel Araştırma Yöntemleri: Beş Yaklaşıma Göre Nitel Araştırma ve Araştırma Deseni. Ankara: Siyasal Kitabevi.

Creswell, J. W., \& Clark, V. L. P. (2007). Designing and conducting mixed methods research. Los Angeles: SAGE.

Çoklar, A. N., Ergenekon, Y., \& Odabaşı, H. F. (2018). Özel eğitimde teknoloji. Pegem Atıf İndeksi, 1944.

Demirel, Ö. (2001). Eğitim Sözlüğ̈̈. Ankara: Pegem. (s. 44-45).

Deniz, M. E. (2017). Erken çocukluk döneminde gelişim. Ankara: Pegem.

Eldeniz Çetin, M., ve Geçal, İ. (2017). Zihinsel yetersizliği olan öğrencilerle çalışan öğretmenlerin eğitimde teknoloji kullanımına yönelik görüşleri ve önerilerinin belirlenmesi. Akademik Sosyal Araştırmalar Dergisi, 5 (52), 624-635.

Ergün, M. (2014). Eğitim felsefesi. Ankara: Pegem Akademi

Ergün-Elverici, S. (2021). Özel eğitim öğretmenlerinin otizmli çocukların eğitiminde teknoloji kullanımına yönelik görüşleri. Turkish Studies - Education, 16(2), 809-822. https://dx.doi.org/10.47423/TurkishStudies.49009

Gay, L.R. (1996). Educational research. Columbus: Merrill Publishing Company.

Harrington, M., DesJardin, J. L., and Shea, L. C. (2010). Relationships between early child factors and school readiness skills in young children with hearing loss. Communication Disorders Quarterly, $32(1), 50-62$.

Hedge, M. N. (2008b). Hegde'spocket Guide to treatmentt in speech-language pathology. (Third edition)

Heward, W. L. (2012). Exceptional children :an introduction to special education.Pearson.

Hourcade, J., Bullock-Rest, N. \& Hansen, T. (2012). Multitouch tablet applicationsand activities to enhance the social skills of children with autism spectrum disorders. Personel and Ubiquitous Computing, 157-168.

Karasar, N. (2008). Bilimsel araştırma yöntemi. Ankara: Nobel Yayın Dağıtım

Kientz, J. A., Goodwin, M. S., Hayes, G. R. \& Abowd, G. D. (2013). Interactive technologies for autism. Synthesis Lectures on Assistive, Rehabilitative, and Health-Preserving Technologies, 2(2), 1-177.

Marschark, M., Rhoten, C., and Fabich, M. (2007). Effects of cochlear implants on children's reading and academic achievement. The Journal of Deaf Studies and Deaf Education, 12 (3), 269-282.

Murdock, L. C., Ganz, J. \& Crittendon, J. (2013). Use of an iPad play story to increase play dialogue of preschoolers with autism spectrum disorders. Journal of autism and developmental disorders, 43(9), 2174-2189.

Newell, L. C., Best, C. A., Gastgeb, H., Rump, K. M. \& Strauss, M. S., 2010. The development of categorization and facial knowledge: Implications for the study of autism. Infant Perception and Cognition: Recent Advances, Emerging Theories, and Future Directions, 223-259.

Okalidou, A., \& Kampanaros, M. (2001).Teacher perceptions of communication impairment at screening stage in preschool children living in Patras, Greece. International Journal of Language and Communication Disorders, 36 (4), 489-502.

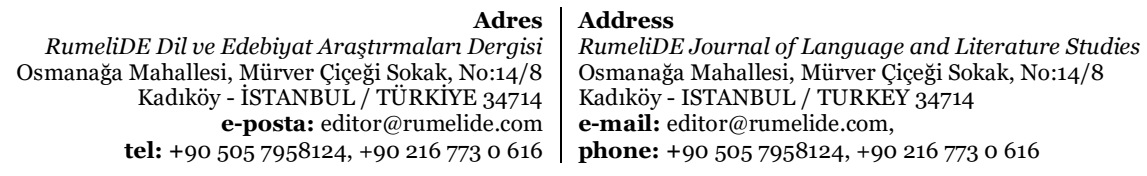


Özdamar, O. (2016). Öğretmenlerin özel eğitim sınıflarında yardımcı teknoloji kullanımına ilişkin görüşlerinin belirlenmesi. (Yayınlanmamış yüksek lisans tezi). Anadolu Üniversitesi Eğitim Bilimleri Enstitüsü, Eskişehir.

Parkman, S., Litz, D., \& Gromik, N. (2018). Examining pre-service teachers' acceptance of technologyrich learning environments: A UAE case study. Education and Information Technologies, 23(3), 1253-1275. https://doi.org/10.1007/s10639-017-9665-3

Paul, R., \& Norbury, C. (2012). Language disorders from infancy through adolescence: Listening,speaking, reading, Writing, and Communicating. St. Louis, MO: Elsevier HealthSciences. Turan, Küçüköncü, Cankuvvet ve Yolal, 2012;

Sadler, J. (2005). Knowledge, attitudes and beliefs of the mainstream teachers of children with a preschool diagnosis of speech/language impairment. Child Language Teaching and Therapy, 21 (2), 147-163.

Sarı, O. (2016). Beceri öğretimi. Kulaksızoğlu, A (Ed.), Farklı Gelişen Çocuklar içinde, (s.189 - 199). Nobel Yayınlart.

Shipley, K. G., \& McAfee, J. G. (2015). Assessment in speech-language pathology: A resource manual. Nelson Education.

Siyam, N. (2019). Factors impacting special education teachers' acceptance and actual use of technology. Education and Information Technologies, 24(3), 2035-2057.Sula ve Spaho, 2014).

Sula, A., \& Spaho, E. (2014). Using assistive technologies in autism care centers to support children develop communication and language skills. A case study: Albania. Academic Journal of Interdisciplinary Studies, 3(1), 203-203.

Şişman, M. (2017). Eğitim bilimine giriş. Ankara: Pegem.

Topbas, S., Konrot, A., \& Basal, M. (1996). A survey regarding the competencies of speech and language pathologists: Perceptions about their current and future competencies. In Annual Congress of CEC-Council for Exceptional Children.

Waddington, H., Sigafoos, J., Lancioni, G., O'Reilly, M., Meer, L., Carnett, A. \& Marschik, P. (2014). Three children with autism spectrum disorder learn to perform a three-step communication sequence using an iPad-based speech speechgenerating. International Journal of Developmental Neuroscience, 59-67.

Yıldırım, A. ve Şimşek, H. (2013). Sosyal bilimlerde nitel araştırma yöntemleri (9. Basım). Ankara: Seçkin.

Yıldız, S. (2010). Bilgi ve iletişim teknolojileri yoluyla özürlüler için geleceğe bir kapı açmak. Journal of International Social Research, 3(11).

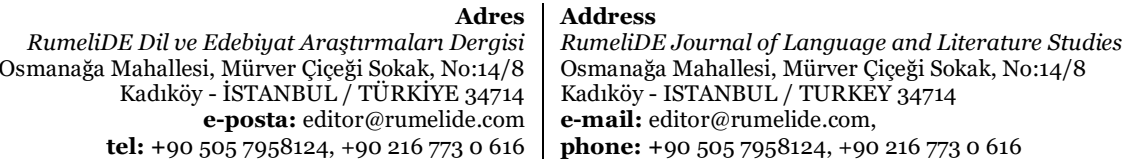

